\title{
Internationalization as a challenge to the impact of globalization: nursing contributions
}

\author{
Dirce Stein Backes ${ }^{1}$, Marli Stein Backes ${ }^{2}$, Valéria Lerch Lunardi ${ }^{3}$, Alacoque Lorenzini \\ Erdmann², Andreas Büscher ${ }^{4}$
}

Today, internationalization should no longer be considered as means to an end but as an end itself. It concerns moving and exchanging to a globalized society without borders, which is focused on knowledge. Besides being a strategic priority of governmental agendas, it is a commitment to be assumed by universities and also by professionals, in general, as a challenge to the impact of globalization.

Globalization has its focus on the global stream of ideas, resources, people, economies, knowledge, goods, services and technologies, while the internationalization emphasizes the relationship between nations, peoples, cultures and values, based on the mobility of human beings.

Thus, the internationalization of higher education is one way to address the impact of globalization ${ }^{(1-2)}$. This process may be related to terms such as education and international cooperation, transnational education, education across borders, education without borders and many others. Whatever the terminology, internationalization - when articulated to the process of globalization - requires new skills of international nature, which generate a series of demands for institutions of higher education, for the profession itself and for researchers ${ }^{(3-4)}$.

The World Declaration on Higher Education for the Twenty-First Century sees the internationalization of higher education as a technology capable of providing unique opportunities to reduce regional inequalities. The United Nations Educational, Scientific and Cultural Organization (UNESCO) displays this phenomenon as a chance to promote social justice and equity, based on solidarity, mutual respect, promotion of humanistic values and intercultural dialogue.

Because it is an irreversible phenomenon of global influence, internationalization has generated a significant impact in the manner of designing health care, as well as in the field of nursing education and investigation. Therefore, it is important for nursing to be prepared to provide culturally adequate care, and to consider the peculiarities of individuals, families and communities in a context in which the languages, cultures, values and needs may be different. The requirement for using common languages, respecting differences and valuing social skills as critical care techniques demand professionals with comprehensive and context-based perceptions, i.e., professionals able to go beyond the limits of their geographical space(5).

The enrollment in a program of international academic mobility reveals advantages of several orders: those associated with scientific production, especially in relation to the advancement of knowledge in regard to research methods and theoretical frameworks, professional training, the exchange of ideas and the contact with theoretical and methodological perspectives that are fields of expertise in others centers of excellence, and even symbolic cultural gains. At the institutional level, it helps to strengthen relationships with institutions recognized by their academic merit, which promote the development and consolidation of scientific, technological and innovation knowledge in the field of interest(2).

When it comes to the Brazilian nursing, an additional boost to the search for internationalization should be credited to the evaluation process of graduate programs and, more recently, to the undergraduate programs, which began to give significant weight to this movement of academic mobility.

In nursing, internationalization has provided a useful stream of knowledge and practices between countries, encouraging the sharing of ideas and practices in order to broaden the horizons of science in Nursing and health. It also resulted in the materialization of several international cooperation programs, such as the creation of the International Council of Nurses (ICN), composed by representatives from 132 countries, the International Classification of Nursing Practice (ICNP), which proposed educational systems by distance, the creation of the Nursing Network for Latin America (REAL), the participation of nurses in editorial boards of international journals and scientific committees, and the International Nursing PhD Collaboration, a collaborative doctorate program in Nursing in partnership with universities in different countries. This last program stands out for developing a network of researchers, professors and students, working on sustainable and long-lasting collaborations, sharing innovative and effective methodologies for studies of nursing care and health promotion according to an international perspective(2-6).

Despite its incipient inclusion in the internationalization movement, nursing has gained important spaces nationally and internationally, through academic exchanges, councils, research networks and international publications in collaboration, in addition to the International Classification of Nursing Practice, among others. It is recognized that many challenges remain, especially those related to the domain of a second language, which have hindered a more proactive integration in the destination countries of the candidates, and especially in the research networking, and in the preparing and publishing materials of collective knowledge.

\footnotetext{
${ }^{1}$ Professor, PhD and Researcher, Franciscano University Center, Santa Maria, RS, Brazil. backesdirce@ig.com.br ${ }^{2}$ Professor, PhD, Federal University of Santa Catarina, Florianópolis, SC, Brazil. ${ }^{3}$ Professor, PhD, Federal University of Rio Grande, Rio Grande, RS, Brazil. ${ }^{4}$ Professor, $\mathrm{PhD}$, Researcher at the University of Applied Sciences - HO, Germany.
} 
Among the strategies to overcome the challenges of internationalization, the following can be highlighted: compulsory learning of a foreign language beginning in primary school years; inclusion of the study of foreign languages in undergraduate nursing programs; the increase in person to person communication and meaningful exchanges with nurses from other countries through social networks; enhancement of the participation of students of all levels in research and extension, as well as encouragement to the practice of reading international scientific literature; the adoption of policies that drive opportunities for international exchange agencies, representatives and institutions; greater investment in infrastructure and professional training of the work done by editors, reviewers and authors of scientific journals, which includes the development and appreciation of their work in a process of continuous feedback; a flexible nursing curricula to facilitate the validation process of disciplines; encouragement of interactive and investigative methodologies, supported by new technologies in order to overcome the teaching methods centered on the professor, especially in disciplines involving international students; expansion of the teaching and research networking through previously planned activities between different actors; fostering bilateral agreements to expand and strengthen collaborative research projects between groups, i.e., the collective production and the exchange of knowledge for economic and social development .

As much as the process of internationalization of higher education and international cooperation has been stimulated globally to meet the needs of the global market, the personal and professional benefits are unquestionable. The internationalization aims, in summary, to value diversity, to understand the characteristics of identity traits, to face diverse and complex scenarios, raising the cultural and social capital, and to add value to professional training and increasing autonomy and resilience, as well as the contribution to the professional and cultural growth of those directly or indirectly involved in the process.

\section{References}

1. Knight J. Internationalization remodeled: definition, approaches, and rationales. J Stud Int Educ. 2004;8(1):5-32.

2. Silva RC, Viana MCA. As implicações de ser um doutorando em Enfermagem no contexto da internacionalização do conhecimento. Esc Anna Nery Rev Enferm. 2013;17(2):207-7.

3. Morosini MC. Internacionalização na produção de conhecimento em IES brasileiras: cooperação internacional tradicional e cooperação internacional horizontal. Educ Rev 2011;27(2):93-112.

4. Organização das Nações Unidas para a Educação, Ciência e Cultura. Conferência Mundial sobre Ensino Superior: as novas dinâmicas do Ensino Superior e Pesquisas para a Mudança e o Desenvolvimento Social; 2009 jul. 5-9; Paris [Internet]. Paris; 2009 [citado 2014 jul. 27]. Disponível em: http://www.Unesco.org/ education/WCHE2009/comunicado_es.pdf

5. Lagunas LF. Internationalization: new challenges for the development of science in nursing and health care [editorial]. Rev Esc Enferm USP. 2013;47(5):1013.

6. Muñoz Gonzalez LA. Academic internationalization [editorial]. Rev Esc Enferm USP. 2012;46(6):1293. 